\title{
PORTER'S FIVE FORCES ANALYSIS FOR NATURAL STONE INDUSTRY AND COMPETITIVE STRATEGIES
}

\author{
Süleyman BARUTÇU \\ Pamukkale University, Turkey
}

\begin{abstract}
In today's very competitive marketplace, an industry analysis is very important to determine reasons, sources and levels of competition in one industry so as to choose suitable competitive management and marketing strategies. In order to evaluate one industry, Michael Porter provided a framework to analyze an industry called as Porter's Five Forces Analysis in the strategic management and marketing literatures. Porter's Five Forces analysis is an important tool for assessing natural stone (Travertine and Marble) industry as well. The main contribution of this study is to combine strategic management and marketing tools and give some recommendations to managers and marketers working in marble and travertine industries. Literature review and analyses indicate that there are very competitive marketplaces in marble and travertine industries not only today but also in the future. However, Turkey will have more competitive advantage in travertine industry than marble industry because of the high travertine reserves. Some competitive management and marketing strategies are also recommended. For example, Turkish natural stone companies should use differentiation strategy instead of cost leadership strategy. In order to increase their sales, they should (1) establish marble and travertine promotion group, strategic supplier alliance, and apply (2) relationship marketing, internet-based marketing, pull and push promotion strategies.
\end{abstract}

Keywords: Industry Analysis, Five Force Analysis, Generic Strategies, Marketing Strategies, Natural Stone, Marble and Travertine Industries

\section{INTRODUCTION}

The natural stone industry is one of the oldest industries in the world. Companies doing business in this industry are facing and will continue to face competition from numerous forces because natural stones and building materials are more popular than ever. Marble, Travertine, Granite and Onyx etc. are some of the natural stone's name. Main uses of natural stones are flooring, exterior and interior cladding, stairs, funeral arts in Turkey and in the world. Moreover, flooring in prestigious admin buildings, schools, airports, hospitals, banks, etc. is laid with elegant looking natural stones like Marble, Travertine or Granite. Therefore, natural stone industry is one of the potential profitable industries in the world.

As with local and international marketing, managers of natural stone companies have to decide how they are to compete and increase their sales. Thus, they should analyze the industry to determine reasons, sources and levels of competition. Porter's Five Forces analysis is a strategic and useful tool used to determine whether one industry is profitable and attractive to start a new business. Successful use of the Porter's Five Forces analysis includes identifying the sources of competition, the strength and likelihood of that competition existing, and strategic recommendations for the action in order to develop barriers to competition. This analysis helps managers understand both the strength of their current competitive position, and the strength of a position they are looking to move into.

The aim of this study is to examine the factors affecting the competition in natural stone (especially marble and travertine) industry not only in Turkey but also in the world. In this study, (1) Porter's Five Forces analysis and the characteristics of marble and travertine industries are explained briefly, (2) these industries are analyzed with Porter's Five Forces analysis in order to determine the sources of competition not only today's competition, but also future competition, (3) based on competitive analysis, some competitive management and marketing strategies like overall cost leadership, differentiation, strategic supplier alliance, 
pull, push, relationship marketing, e-commerce, marble and travertine promotion group etc. are given.

\section{PORTER'S FIVE FORCES ANALYSIS}

Porter (1980) provided a dynamic and focused structural analysis of an industry called Porter's Five Forces analysis in the literature. This analysis is a simple but powerful model to determine competition level in an industry. In terms of Porter's Five Forces framework, the strengths of the company are determined by its competitive position under five forces. Managers and academicians can use Porter's Five Forces analysis to determine the competition level and attractiveness of the analyzed industry, evaluate its position, and construct strategies to gain a competitive advantage.

Porter's Five Forces analysis is used in many studies in the literature. For example, Thurlby (1998) used this stratey to give companies the necessary insights to enable them to formulate the appropriate strategies to be successful in electricity industry; Watson (2000) benefited from Porter's Five Forces analysis to examine the strategic considerations of investing in higher education and in particular, competitive challenges presented by both existing institutions and new education providers; Jasimuddin (2001) analyzed the competitive advantages of Saudi Arabia with Porter's model; Slater and Olson (2002) emphasized that Porter's Five Forces analysis had a good framework for industry analysis and the development of a strategy for competitive advantage; Pines (2006) provided an insight into the economics of emergency care by showing how the forces of supplier power, buyer power, threat of substitution, barriers to entry, and internal rivalry affect Emergency Medicine industry; Jin and Moon (2006) analyzed competitiveness of Korea's apparel industry using Porter's Five Forces anaysis, and Orel and Mistıkoğlu (2007) used Porter's Five Forces analysis for competitive analysis of the Turkish brick industry. Karagiannopoulos et al. (2005) criticized Porter's thoughts concerning internet and industry structure. They analyzed the impact of the internet on "traditional" market rules and the way a company must formulate its business strategy. After re-evaluating Porter's Five Forces model, the use of the "power of innovation" is proposed as an additional profit factor within industry to enrich the Porter's Five Forces analysis, since the availability of e-commerce and Internet marketing are very important for competition level in an industry.

The competitiveness of an industry is influenced by five forces and the collective strength of these forces determines the ultimate profit potential of an industry. If the each force has high power, companies do not determine the prices of products easily and get high profits. In contrast, if the each force has low power, companies can determine the prices of products and get higher profits easily (Thomson et al, 1995). In this sense, low power of each force is good for companies and high power of them is good for final customers or end-users. As seen in Figure 1, these five forces covered in the analysis are competitive rivalry, supplier power, buyer power, the threat of substitution and the threat of potential new entry.

Competitive rivalry refers the strength of competition in the industry. The main factors that tend to increase rivalry among industry competitors are; the number of rivals, numerous equally balanced rivals, high fixed costs of production, low differentiation, low switching costs, culturally diverse competitors, slow growth of the industry, concentration, brand identity, informational complexity, diversity of competitors, corporate stakes, and exit barriers. Therefore, these factors affect competition among companies in the industry.

The threat of new entry refers the ease with which new companies of competitors can enter the market. The new entrants to an industry can threaten existing competitors, because they bring additional production capacity. The key concept in analyzing the threat of new entrants is the entry barriers. If a company finds entry into a new industry difficult or a competitive disadvantage, entry barriers exist. Every industry has its special characteristics that may restrain new entries. Some common factors that raise barriers of entry are: long-term relationships with the customers, capital requirements, economies of scale, switching costs differentiation, and government policies. If new competitors can quickly enter the industry and the industry has low growth rate, these weaken companies' power. In contrast, the high industry growth rate and high entry barriers to industry are advantageous for existing companies in the industry.

Buyer power refers the power of your customers to drive down your prices. How easy it is for buyers to drive prices down shows bargaining power of buyers. This power is driven by the number of buyers, the importance of each individual buyer in an industry, switching cost from one supplier to other suppliers, and so on. If a company deals with few and powerful buyers, these powerful buyers will be able to force their wants and control the company easily. Buyer 
power increases with the buyers' purchasing power from the same supplier in large amounts, standardized or undifferentiated products, low switching costs, threat of backward integration, purchase being not important for the buyers.

Threat of substitution refers the extent to which different products used in place of your companies' products or offered by other industries. The number of substitute products and the cost of switching them affect the treat of substitution. If the customer or company has low switching costs to substitute products, threat of substitutes will be very high. In contrast, if substitution is not easy, this strengthens companies' power in the industry.

\section{Figure 1. Porter's Five Forces Model}

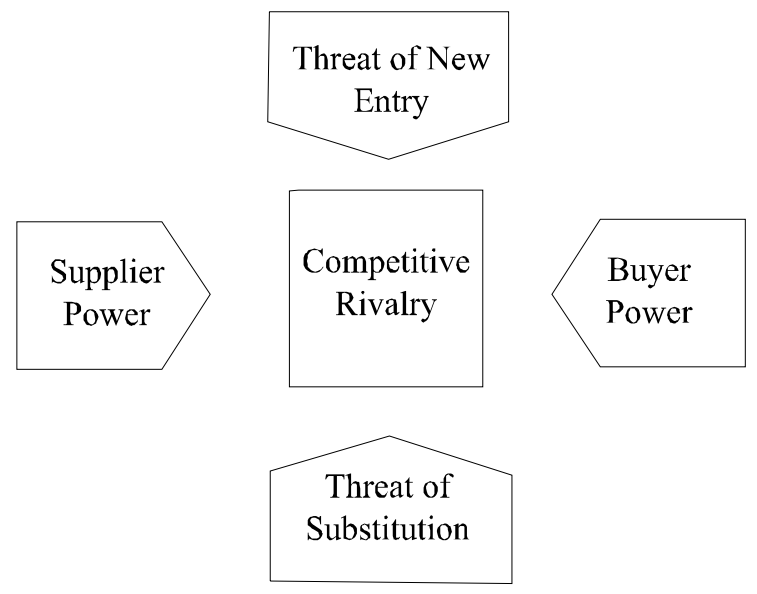

Source: Porter, M. E. (1980) Competitive Strategy, Techniques for Analysing Industries and Competitors, The Free Press, New York, USA, p.4

Supplier power refers the power of suppliers to drive up the prices of your raw materials, supplies, equipments or inputs. If the suppliers can change the price of products and drive up prices easily, they have power. Suppliers have control over the competition in the industry through their bargaining power. Few suppliers, no substitutes to the supplier's products and high switching costs from the supplier increase supplier's bargaining power.

\section{NATURAL STONE IN DUSTRY N TURKEY AND IN THE WORLD}

In the global natural stone industry, international competition is observed among limited countries like
Italy, Spain, Portugal, Greece, Turkey, Iran, India, Brazial, Mexico, Peru, Egypt and China which have had important progress in recent years. Today, twelve countries account for $73 \%$ of the world natural stone production. Turkey is in $7^{\text {th }}$ place among natural stone producers, and $12^{\text {th }}$ among exporting countries (Çalapkulu, 2003). In natural stone industry, one of the most important countries is Italy. In the first nine months of 2006, Italy exported marble and granite for a total of 2,371,895 tons, worth 1 billion 321 million euros. The export figures for the most significant items see a rise in the amounts of marble and travertine (Exports of Italian marble and granite still on the rise, 2007).

Over the last few years, much of international attention in natural stone industry has been centered around China and India both for their competitive pricing and technological progress. Meanwhile, Turkey moved into marble and travertine industries. Presently, Turkey is one of the few countries in the world, capable of producing over 5 million $\mathrm{m}^{3}$ of rough blocks and is now beginning to play an important role on the international market, particularly in finished marble and travertine products. This means strong competition for some of the well established stone producing countries, particulary Italy (Turkey at the Tops of the Worlds, 2006) and China.

Turkey's marble and travertine production have grown tremendously in the last few years. Turkey, with an important place in terms of the world's travertine reserves, has a very high market opportunity with its variety of marble having about 400 different color and texture qualities (Nasuf, 2003). Turkish marble presents much variety of colors, and its great beauty is well known. It is especially well adapted interior and exterior decoration purposes in buildings. Especially, Denizli Travertine is very special natural stone mined in limited countries in the world. Although Turkey is rich in terms of the marble and travertine reserves, it is not up to the sufficient production level with respect to reserves. Turkey has almost $40 \%$ of the total marble and travertine reserves or block production capacity (13.9 billion tons) of the world with 5.2 billion tons. However, only $1 \%$ of these reserves are currently being utilized and the marble and travertine production of Turkey have shown a gradual increase in production and export in the world starting from 1980s (Çetin, 2003). In other words, Turkey provides approximately $3 \%$ of the world natural stone production and exports just a little more than $2 \%$ of total exports by weight (Çalapkulu, 2003). Therefore, if Turkish natural stone companies utilize marble and travertine reserves, Turkey can 
Table 1. Marble and Travertine exports of Turkey (US\$)

\begin{tabular}{|c|cc|c|c|c|}
\hline Year & Marble & Travertine & Year & Marble & Travertine \\
\hline 1989 & $26,850,615$ & $1,439,752$ & 1997 & $71,903,074$ & $14,408,843$ \\
\hline 1990 & $35,213,684$ & $1,952,804$ & 1998 & $72,391,793$ & $24,026,117$ \\
\hline 1991 & $34,465,264$ & $2,371,270$ & 1999 & $88,839,394$ & $38,228,000$ \\
\hline 1992 & $40,182,463$ & $2,263,953$ & 2000 & $93,948,021$ & $61,654,653$ \\
\hline 1993 & $42,071,788$ & $4,018,961$ & 2001 & $112,032,120$ & $77,190,551$ \\
\hline 1994 & $51,228,703$ & $4,927,816$ & 2002 & $126,529,445$ & $123,942,145$ \\
\hline 1995 & $60,533,576$ & $6,532,383$ & 2003 & $172,498,953$ & $179,765,150$ \\
\hline 1996 & $62,735,82$ & $12,363,028$ & Total $(\$)$ & $1,091,424,721$ & $555,085,426$ \\
\hline
\end{tabular}

Yüzer, E., Mutlu, S. (2005) Stone 2005 Doğal Taş ve Endüstrisi Kataloğu (Natural Stone and Industry Catalog), Yapı Yayın, İstanbul, p.23

become the biggest marble and travertine exporter in the world.

Marble and travertine exports of Turkey are given in Table 1. The total marble and travertine exports increased from 1989 to 2003 gradually. For example, the difference in total marble and travertine exports from 2002 to 2003 was $40,64 \%$, correspondingly $\$ 250,471,590$ and $\$ 352,264,103$.

The leading buyers of finished marble and travertine exports from Turkey are in the United States. The US market prefers light cream/brown colors, and Turkish travertine is lighter in color than stone from Mexico or Peru (Market Perception Survey, 2006). Exports to the United States excelled in 2001 figure of $\$ 46$ million by $49 \%$ to $\$ 68,7$ million in 2002 . United Kingdom, Saudi Arabia and Italy were some of the most important countries imported travertine from Turkey (Processed Travertine exports of Turkey, 2003). The majority of marble imports in the United States are from Italy at $40 \%$, however, other countries such as Brazil, China, India and Turkey, are quickly gaining market share. Turkey exported to the US more finished products than Italy in 2005. There are several reasons for Turkey's growth; other than endless reserves of a wide variety of attractive high quality marble and travertine, the technology and ability to compete on the world markets of Turkish marble companies (Turkey at the Tops of the Worlds, 2006). Italy also imports marble and travertine rough blocks (unprocessed marble blocks) from different countries. Turkey is one of the important suppliers of Italian companies (Exports of Italian marble and granite still on the rise, 2007). After Italian companies import rough blocks from Turkey, they process them. Afterwards, they export finished travertine and marble to the United States with their own brand name and get higher added value than Turkish natural stone companies.

\section{PORTER'S FIVE FORCES} ANALYSIS FOR TRAVERTINE AND MARBLE INDUSTRIES

Understanding of competition level in the marble and travertine industries, Porter's Five Forces model provides one way to present the current position and presents an insight into marble and travertine industries by showing how the forces of supplier power, buyer power, threat of substitution, barriers to entry, and internal rivalry. As seen in Figure 2, these industries are analyzed as using Porter's Five Forces model as following:

Internal competitive rivalry among marble and travertine companies are high. There are a lot of existing companies competing in the market from different countries. All companies in these industries are effectively competing with among them. The intensity of rivalry is influenced by the following industry characteristics: (1) a larger number of companies increase rivalry, because more companies must compete for the same customers, (2) slow market growth causes marble companies to fight for market share, (3) low switching costs increase rivalry. More and more natural stone are also competing to reach more potential customers not only in their local markets but also in international markets. Therefore, competitive rivalry in marble and travertine industries are extremely high and intense competition among them puts strong downward pressure on prices. Unless demand of them increases not only local markets, but also international 


\section{Figure 2. Porter's Five Forces model adapted for the marble industry}

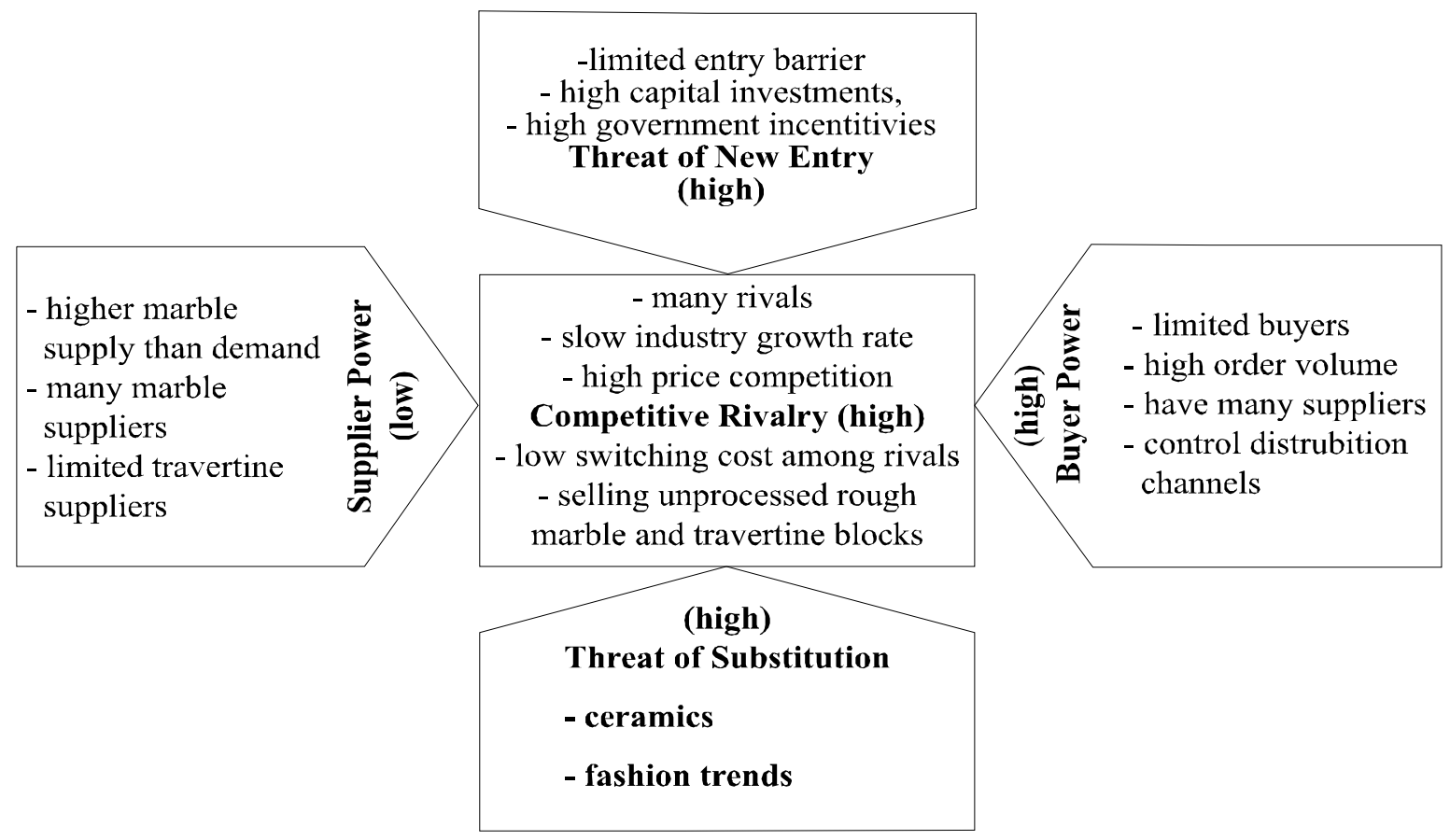

markets, high competition is expected to continue following years in marble and travertine industries.

The possibility that new companies may enter the industry also affects competition in an industry. The threat of new entry to marble and travertine industries is high, because these industries do not have significant barriers to entry. Although to start a new business in marble or travertine industries requires a significant amount of capital investments, there are many government incitements in developing countries like China, India and Egypt. Therefore, new competitors can come into the industries easily from different countries and reduce industries' profit margin. As a result, the marble and travertine industries are very competitive and have matured over the years after the massive entry from different countries like Turkey, China and India since the early 1980s. On the other hand, the threat of new entry to travertine industry will be low in the future, because it is mined in limited countries and Turkey has the biggest travertine reserves in the world.

Buyer power is the impact that purchasers and intermediaries have on the marble and travertine industries. Although there are many companies and different marble and travertine available in the markets, there are limited buyers and big wholesalers. The marble and travertine industries companies do not have a significant level of power over the buyers, because the buyers have high volume order and control the distribution channel. All producers of them are competing to attract consumers' and intermediaries' attention by providing the best quality and great price. Therefore, the buyers have the greatest power, set the price for them and imply strong downward pressure on prices.

There is relatively high threat from substitute of marble and travertine products. Ceramics, granite and different kinds of natural stones can be used instead of marble and travertine in buildings to be decorated for centuries. As improved production techniques made ceramics readily available, at affordable costs, for a full range of architectural applications. Moreover, ceramics can also be designed as marble or travertine. Therefore, threat of ceramics as substitute products has been experienced throughout the industries. The definition of a supplier in these industries is a company mined marble and travertine. Although just twelve countries account for $73 \%$ of the world natural stone production, there are many marble suppliers and producers in the world. Moreover, marble supply is higher than demand and suppliers have to compete with among them. In contrast, even though most of the travertine is mined in Turkey, there are many travertine suppliers in Turkey. Therefore, supplier power is very low in marble and travertine industries. In the future, Turkish travertine companies will have competitive advantage and will get higher profits, because Turkey has the 
biggest travertine reserves in the world.

\section{COMPETITIVE MANAGEMENT AND MARKETING STRATEGIES}

The marble industry is highly competitive, because of high competitive rivals, buyer power, ceramics substitution and new entry to marble industry from different countries. Even though demand of marble grows every year, this demand growth rate is not enough. By using competitive management and marketing strategies, the demand of marble could be increased.

\section{Management Strategies}

Porter $(1980 ; 2004)$ has presented three generic strategies for improving the competitive position of a company: cost leadership, differentiation, and focus to better compete in either local or international markets. These generic strategies have been one of the most widely accepted methods of discussing, categorizing, and selecting company strategies. A company will have to make a choice among these generic strategies if it is to achieve a competitive advantage (Akan et. al. 2006). As seen in Figure 3, each of the three strategies is considered within the context of two aspects of the competitive environment as sources of competitive advantage and competitive scope of the market. Sources of competitive advantage refer the products differentiated in any way, or the lowest cost producer in an industry. Competitive scope of the market refers the company target a wide market, or focuses on a very narrow, small segment or niche market.

\section{Figure 3. Porter's competitive generic strategies}

Competitive Advantage

\begin{tabular}{|c|c|c|}
\hline & Lower Cost & Differentiation \\
\hline & Cost Leadership & Differentiation \\
\hline 离 & Cost Focus & $\begin{array}{l}\text { Differentiation } \\
\text { Focus }\end{array}$ \\
\hline
\end{tabular}

Source: Adapted from Porter, M. E. (2004) Competitive Strategy: Techniques for Analyzing Industries and Competitors, The Free Press, New York, USA, p.396
The cost leadership strategy is based on the concept that you can produce and market a good quality product or service at a lower cost than competitors. These low costs should translate to profit margins that are higher than the industry average. Some of the conditions that should exist to support a cost leadership strategy include the pursuit of economies of scale, low labor costs, high government incitements and other factors. In cost leadership, a company sets out to become the low cost producer in its industry. A low cost producer must find and exploit all sources of cost advantage. In marble and travertine industries, because of the Chinese government incitements and low labor cost, Chinese marble companies offer the cheapest price in the world. Turkish marble and travertine companies should not use this strategy, because the costs of logistics, labor, and energy etc. are very high in Turkey. In a differentiation strategy a company seeks to be unique in its industry along some dimensions that are widely valued by buyers. This uniqueness should also translate to profit margins that are higher than the industry average and is rewarded for its uniqueness with a premium price. In marble industry, mining different marble from different countries in the world is a good reason to use differentiation strategy. In addition, some of the conditions that should exist to support a differentiation strategy include a good reputation, strong marketing abilities, brand name, faster production and distribution abilities and etc. In travertine industry, companies can use differentiation strategy, because Turkey has one of the highest travertine quality and reserves in the world.

Companies may also choose a combination strategy by mixing of generic strategies. The focus strategy can be adopted by differentiators or cost leaders, but differs in that it targets a market niche rather than the broad market. In cost focus a company seeks a cost advantage in its narrow target segment, while in differentiation focus a company seeks differentiation in its narrow target segment. The narrow target segments must either have buyers with unusual needs or else the production and delivery system that best serves the target segment must differ from that of other industry segments. The focuser selects a segment or group of segments in the industry and tailors its strategy to serving them to the exclusion of others. The Turkish marble companies should select target customers and differentiate their marble to offer hotels, houses, and buildings.

In addition to Porter's generic strategies, Turkish marble companies should persuade their buyers or distributors to establish strategic supplier alliance. 
customers and differentiate their marble to offer hotels, houses, and buildings.

In addition to Porter's generic strategies, Turkish marble companies should persuade their buyers or distributors to establish strategic supplier alliance. The marble companies should realize that architects, building contractors, suppliers, buyers, and logistics providers are an essential part of success. Strategic supplier alliances is a strong relationship formed among companies in marble supply chain to achieve specific objectives and benefits. It is usually established to increase operational performance of each member through reductions in total production, inventory, and quality control costs, and increased shared information and profits. Rather than concerning themselves only with price, companies are looking to suppliers to work cooperatively in providing improved services, innovations and product design (Maloni and Benton, 1997). Therefore, the competitiveness in global economy requires companies to focus on core competencies, reduce their number of suppliers and develop strong partnership built on shared information and trust with the remaining suppliers (Stuart and McCutcheon, 2000). Doing business with appropriate suppliers formed strategic supplier alliances is beneficial for the marble and traverine companies to provide a continuous and sufficient production volume with higher quality as well. Since Turkey has high resources of the natural stones, companies set up factories in China with partnership in order to benefit from low labor and production costs in China in order to compete with Chinese natural stone companies.

\section{Marketing Strategies}

Competitive marketing strategies have a key role to reach in market success in order to increase sales, maintain or improve market share, create a favorable climate for future sales, and create a competitive advantage over competitor's products or market position. Successful marketers are those who can steer their companies through the competitive marketing environment, and do it better than competitors. Although the industry trends indicate that the future of marble and travertine may move towards more price competition, companies look for new ways to be more competitive. Turkish natural stone companies should use marketing strategies except for lower price. What can marketing managers of companies do to improve their market position? There are many marketing strategies related marketing mix (4Ps; Products, Price, Promotion, Place) used in marble industry. Therefore, some of them are briefly explained below.

There are three associations (The Istanbul Mine Exporters Association, The Aegean Mine Exporters Association and Association of All Marble, Natural Stone and Machinery Producers) unceasingly working to improve Turkey's production of natural stones and exports. They also should establish "Marble and Travertine Promotion Group". The main task of this group should organize and execute advertising and promotion activities aimed at increasing local and international marble and travertine demand not only in Turkey, but also in the world. In the future, if the marble and travertine markets do not grow, the profitably and attractiveness of these industries will decrease. Advertising and promotion activities in the targeted markets such as the United States, European Union, Japan, China and etc. should be performed by the group in these countries to increase marble and travertine demand. Moreover, they should open

\section{Figure 4. Pull and Push Strategies in promotion and marketing}

Push Strategies
Marketing Activities
Producer

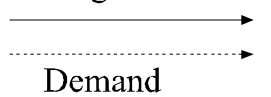
Intermediaries
Wholesaler-Retaliers
Marketing Activities

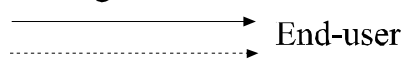
Demand

Pull Strategies

Marketing Activities

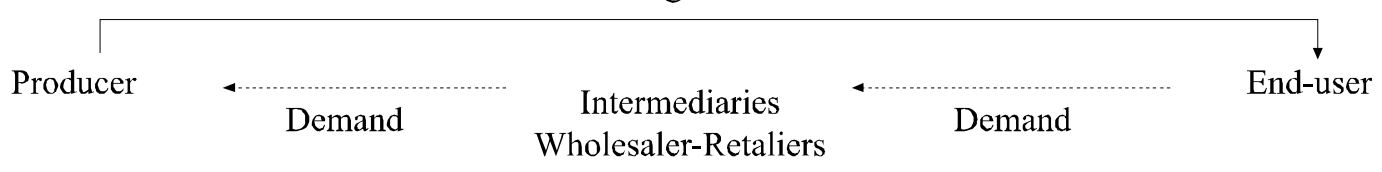


showrooms, warehouses and set up distribution channels in some of the countries importing marble and travertine from Turkey.

In marble industry, competitive marketing strategies are very important instead of low price competition. For example, promotion is an important component of the marketing mix. Promotional approaches include advertising, direct marketing using e-commerce and e-marketing, sales promotions, public relations, publicity and personal selling etc. Moreover, fairs, seminars, presentations and exhibitions are also very important to promote marble and travertine as the doors of the industry to buyers. Marketing theory distinguishes between two main kinds of promotional strategy; pull and push. In particular, the decision to use a pull or a push strategy determines whether promotion is focused on intermediaries or on endusers (Figure 4). It is more important to define exactly who decides to buy marble products than who buys marble products. The appropriate communication channels in these two strategies are very different.

A push promotional strategy makes use of a company's sales force and trade promotion activities to create consumer demand for a product. Promotional activities to intermediaries, such as retailers, wholesalers or architects are described as push strategies, and rely on intermediaries selling the product to the end-user. In push strategy, the producer promotes the product to wholesalers, the wholesalers promote it to retailers, and the retailers promote it to consumers. For example, natural stone companies should promote their products to architect, wholesalers and retailers. In reality, architects are the true target customers for the majority of the marble products in the world. In general, architects have a great deal of power over end-user customers, because they decide which materials are used in houses, hotels, places, buildings in design stage. Therefore, marble companies should also target the architects. In contrast, a pull strategy is one that requires high spending on advertising and consumer promotion to build up consumer demand for a product. In this strategy, consumers will ask their retailers for the product, the retailers will ask the wholesalers, and the wholesalers will ask the producers. Direct promotion to end-users is designed to encourage endusers to ask for certain features or products from intermediaries.

In addition to promotion strategies, Turkish marble and travertine companies can use relationship marketing approach to develop long-term customer relationship and supply individualized marketing mix (4Ps). There has been a gradual move in marketing thought and practice: mass marketing, market segmentation, niche marketing, and finally relationship marketing. Relationship marketing is becoming increasingly important to the overall marketing strategies of many companies. Grönroos (1994) defined that relationship marketing is to identify, establish, maintain and enhance relationships with customers and other stakeholders, at a profit, so that the objectives of all parties are met. Perrien and Ricard (1995) defined relationship marketing as an asymmetrical and personalized marketing process. Goldsmith (1999) explained that managers must consider the extent to which they should personalize the product, making it unique for each individual customer. According to the authors, this process takes place in long run, results in some bilateral benefits, and rests on an in-depth understanding of customer needs and characteristics. Peppers et al. (1999) explained four key stages for putting a relationship marketing program to work: (1) identifying the customers, (2) differentiating them, (3) interacting with them, and (4) customizing your product or service to fit each individual customer's needs. Therefore, Turkish marble companies should develop long-term customer relationships with their buyers and intermediaries and offer marble products what individual customer wants.

Another important marketing strategy and tool is internet-based marketing. The internet is revolutionizing marketing, retailing, shopping and advertising activities of products, services and natural stones as well. Internet allows suppliers, producers, intermidiaries and customers to meet at electronic marketplace in order to search, order, sell products and services or communicate among them efficiently. Internet, e-marketing (internet marketing or online marketing) e-commerce (electronic commerce) have had a huge impact on business. By using the internet, travertine and marble can sell directly to customers or traditional intermediaries (wholesalers, retailers) and provide customer support online. E-commerce and Internet make possible an increased number of competitors in marble industry without respecting to geographic location and increased their sales. On the other hand, Internet increases competition in marble industry, because buyers use internet to search marble companies offering the lowest price in the world. It causes more competition among marble and travertine industries in the world. In spite of these advantages and disadvantages, nowadays, e-marketing, eadvertising and e-commerce are no longer an alternative, they are an imperative in competitive marble and travertine industries. Many companies in these industries are competing to gain maximum 
benefits from the e-commerce. There are many marble and travertine e-commerce portal in internet. For example, www.travertenmermer.com/index.htm, www.e-maden.net, www.alibaba.com and www.trextile.com are some of them.

\section{CONCLUSION}

The aim of this study is to undertake an analysis of marble and travertine industries and form a basis for the future strategies for companies. In order to achieve this, Porter's Five Forces model is utilized as a framework. Analyzing the marble and travertine industries using Porter's Five Forces model makes it clear that there are very competitive business environment not only today but also in the future. The five forces presented in this model are the degree of rivalry, the supplier power, the buyer power, barriers to entry, and the threat of substitution. Strong buyer power, high rivalry, low cost ceramics substitute, threat of new entrants makes marble and travertine industries very competitive. Many companies in the world entry into these industries and compete on the consumer to offer marble and travertine that are highly differentiated and affordable prices. Moreover, this highly competitive environment will be expected to continue in marble industry. In contrast, travertine industry will be less competitive in the future, because of uniqueness of travertine.

Nowadays, Turkey faces with high competition from the marble and travertine industries of Italy, China and a few more countries in the world. Moreover, countries such as Italy and China import rough marble and travertine blocks from Turkey, process, and then export them with higher price from their production points. This situation is not profitable for Turkish marble and travertine industries. They should process their own natural stones, and then export them with their own brand name, because finished marble and travertine add more value to country where they are extracted. The competition in these industries is not only affected by existing rivals, low entry barrier, buyers' power and substitute products, but also affected by government incitements. The cost of energy and labor seems to be undoubtedly at the head of the basic elements affecting costs in marble and travertine industries. In marble and travertine industries, it should also be analyzed the role of the government incitements on the competitiveness of these industries. Turkish marble and travertine companies have difficulty in cost perspectives. Turkish governments should also give direct and indirect incitements to these industries just like Chinese government does.
Depending on the marketing and management literatures, many strategies can be recommended to Turkish travertine and marble companies. First of all, to survive in highly competitive industries, it is vital that marble and travertine companies can produce market, brand, and distribute their products better than their competitors and try to develop barriers to marble and travertine industries. Marketers may choose push strategy aimed at intermediaries and architects in international markets instead of pull strategies in order to persuade them. The reasons why marketers should use pull strategy are that architects play an important role in designing the buildings, houses, hotels or places and intermediaries play significiant effects to convince on potential customers to prefer travertine and marble products.

Italian companies use the differentiation strategy and Chinese companies use cost leadership strategy in natural stone industry. In other word, while Italy is able to market high quality, branded and differentiated marble and travertine, Chinese have done so by aggressively marketing and by offering at the cheapest prices in the world. On the other hand, Turkey has the ability to manufacture high quality travertine and marble at reasonable prices and is still not able to adopt either the Italian or the Chinese ways. Turkish marble companies should not use cost leadership strategy, because the cost of natural stone mining and producing is very low in China and Chinese government gives some important incitements to their natural stone companies. Instead of cost leadership strategy, Turkish natural stone companies may choose a focused differentiation strategy. They should also try to establish strategic supplier alliances with buyers or intermediaries and choose a segment or group of segments and customize their strategies. After applying successful management and marketing strategies, Turkish marble and travertine will become well known in the market and reach the real market value. For future research, there will be a survey to determine owners and managers' attitudes towards these marketing, management or new strategies carrying out in marble and travertine industries. 


\section{REFERENCES}

Akan, O., Allen, R. S., Helms, M. M., Spralls III, S.A. (2006) Critical tactics for implementing Porter's generic strategies, Journal of Business Strategy, Vol. 27 (1), 43-53

Çalapkulu, F. (2003) Turkey And Other Players In The Global Natural Stone Industry, Retrived April 5, 2007 from http://www.turkishtime.org/ sector_1/108_eng.asp

Çetin, T. (2003) Türkiye Mermer Potansiyeli, Üretimi ve İhracatı, Gazi Eğitim Fakültesi Dergisi, Cilt 23 (3), 243-256

Exports of Italian marble and granite still on the rise (2007) Retrieved April 6, 2007 from

http://www.marbleandmore.com/EN/Economy-andTrends/Exports-of-Italian-marble-and-granite-stillon-the/news.htm? $\mathrm{n}=528$

Goldsmith, R. E. (1999) The personalised marketplace: beyond the 4Ps, Marketing Intelligence and Planning, Vol. 17 (4), 178-185

Grönroos, C. (1994) From marketing mix to relationship marketing: Towards a paradigm shift in marketing, Management Decision, Vol.32 (2), 4-20

Jasimuddin, S. M.(2001) Analyzing the competitive advantages of Saudi Arabia with Porter's model, Journal of Business \& Industrial Marketing Vol. 16 (1), 59-68

Jin, B., Moon, H.C. (2006) The diamond approach to the competitiveness of Korea's apparel industry Michael Porter and beyond, Journal of Fashion Marketing and Management Vol. 10 (2), 195-208

Karagiannopoulos, G.D., Georgopoulos, N., Nikolopoulos, K. (2005) Fathoming Porter's Five Forces model in the internet era, Info, Vol. 7 (6), 6676

Maloni, J.M., Benton, W.C., (1997) Supply Chain Partnership: Opportunities for operations research, European Journal of Operational Research, Vol.101, 419-429

Market Perception Survey (2006) TURKEY -US

Business Partnering Alliance, retrieved April 6, 2007 from

http://www.taik.org/db/Docs/Marble\%20and\%20St one $\% 20$ Survey.pdf

Nasuf, E. (2003) The Marble Sector from a Different Perspective, retrieved April 6, 2007 from www.turkishtime.org/sector_1/18_eng.asp
Oral, E. L., Mistıkoglu, G., (2007) Competitive analysis of the Turkish brick industry- a case study for developing countries, Building and Environment, Vol. 42 (1), 416-423

Peppers, D., Rogers, M., Dorf, B. (1999) Is Your Company Ready For One-To-One Marketing?, Harvard Business Review, January-February, 151-160

Perrien, J., Richard, L. (1995) The Meaning of a Marketing Relationship: A Pilot Study, Industrial Marketing Management, Vol. 24 (1), 37-43

Pines, J. M. (2006) The economic role of the emergency department in the health care continuum: Applying Michael Porter's Five Forcess model to emergency medicine, Journal of Emergency Medicine, Vol.30 (4), 447-453

Porter, M. E. (1980) Competitive Strategy, Techniques for Analyzing Industries and Competitors, The Free Press, New York, USA

Porter, M. E. (2004) Competitive Strategy: Techniques for Analyzing Industries and Competitors, The Free Press, New York, USA

Processed Travertine exports of Turkey (2003) Retrived April 6, 2007 from www.inspectstone.com/ins/article/ stoneexport/prctravexp.asp

Slater, S. F. Olson, E. M. (2002) A fresh look at industry and market analysis, Business Horizons / January-February, 15-22

Stuart, F., I., McCutcheon, D.M., (2000) The Manager's Guide to Supply Chain Management, Business Horizons, Vol. 43 (2), 35-44

Thomson, A.A., Strickland, A.J. (1995) Strategic Management, 8th Edition, USA

Thurlby, B. (1998) Competitive forces are also subject to change, Management Decision, Vol. 36 (1), 19-24

Turkey at the Tops of the Worlds (2006) Retrieved April 5, 2007 from

www.marbleandmore.com/EN/news/ Countries-andMarket/Countries-and-Market/Turkey-at-the-tops-ofthe-worlds/news.htm?n=454

Watson, P. (2000) Barriers to entry: implications for private finance initiatives in university provision, Journal of Workplace Learning Vol. 12 (3), 100-110 www.alibaba.com www.e-maden.net www.travertenmermer.com www.trextile.com 